\title{
Arbor
}

\section{Programa iconográfico para la decoración escultórica del Palacio Real Nuevo de Madrid}

\section{$M^{a}$ Jesús Herrero Sanz}

Arbor CLXIX, 665 (Mayo 2001), 29-57 pp.

Un incendio ocurrido durante la noche del 24 de diciembre de 1734, destruyó violentamente el antiguo Alcázar o Palacio de los Austrias, en Madrid. Este hecho obligó a Felipe V a planear la construcción de una nueva residencia regia. El suceso, que no pudo ser más inesperado y fortuito, marcó una nueva fase en la evolución de las artes en España, sobre todo en la escultura, con la entrada de nuevos artistas extranjeros, que fueron llamados por los Monarcas Españoles para trabajar en las obras del Nuevo Palacio.

No cabe duda de que el arquitecto encargado de la edificación del Palacio Nuevo, Sacchetti, tenía en mente dotarle de algunos adornos escultóricos ideados por él mismo, pero estos ornatos eran convencionales e iguales a los de cualquier obra arquitectónica lujosa y regia. El Palacio Madama de Turín, con sus figuras alegóricas, constituía un modelo a seguir.

La primera noticia de un programa unitario es la orden cursada, en 1742, al escultor Juan Domingo Olivieri ${ }^{1}$, que proporcionó algunas ideas sobre las esculturas para decorar el Palacio, ofreciendo varias opciones para que el Rey eligiese la más adecuada. Pero las propuestas no fueron aceptadas, por comprender ideas demasiado generales que tanto convenían al Palacio de España como al de otra cualquiera Nación ${ }^{2}$. Desconocemos el contenido de este primer proyecto del que podemos hacernos una idea a través de las remodelaciones posteriores, así como de otro mencionado en el que interviene Sacchetti. 


\section{$M^{a}$ Jesús Herrero Sanz}

Tanto este primer proyecto como el segundo se mezclan de una forma tan confusa, y las alusiones son tan poco claras, que no podemos conocer con certeza hasta qué punto se desarrollaron uno y otro. Indirectamente los Padres Fèvre y Sarmiento suministran algunas noticias de cómo eran estos primeros proyectos al redactar los suyos propios, ya que en buena medida partieron del mismo punto. El Doctor Plaza Santiago dio a conocer una serie de dibujos donde podemos contemplar la decoración propuesta en el proyecto de 1742. Los «trofeos», muy abundantes, se colocarían en los remates de las fachadas de las torres y en los cuatro machones de la fachada principal, bajo el balcón. Igualmente, se insiste en la colocación de, 52 cabezas de máscara, mitad de una figura y mitad de la otra, que han de servir de ornato a los frontispicios de las ventanas del cuarto principal. Sin embargo, se plantea un problema con el número de esculturas para la balaustrada. Según el Padre Sarmiento, Olivieri había contemplado un total de cincuenta y dos posibles estatuas para que el Rey eligiera las veintiséis que fueran más de su agrado ${ }^{3}$.

Además de los relieves, Olivieri también había dispuesto dieciséis estatuas de bulto completo para las balaustradas del patio, cuyos temas eran doce alegorías de Virtudes que repetirá el Padre Sarmiento -Gratitudine, Libertà, Historia, Concordia, Obediencia, Obligo, Gioia, Libertá, Tranquilitá, Perfeccione, Chiarezza, Armonia, Amicizia- y las cuatro mujeres fuertes de la Biblia. Para la Escalera Principal proponía los retratos del Rey y de la Reina, y ocho virtudes de ambos: Giusticia, Fortaleza, Temperanza, Prudenza, Magnanimità, Magnificenza, Forza, Valore. Ya hemos comentado que estas ideas merecieron críticas por su carácter excesivamente general y por su poca adaptación a la significación concreta del edificio al que se destinaban, de forma que buscaron proyectos más adecuados.

\section{El proyecto del Padre Fèvre}

El jesuita francés hizo también un proyecto de decoración, probablemente, en las mismas fechas que el Padre Sarmiento, pero su desarrollo se conoce mal. Los únicos documentos de primera mano que se pueden consultar son los pocos papeles de 1745, conservados en el Archivo Histórico Nacional ${ }^{4}$. En ellos se detalla la ornamentación relativa a la Escalera Principal y se expresan opiniones de gran interés, ya que sirven, indirectamente, para conocer el primer programa decorativo del escultor y del arquitecto principales. Para la Escalera 
Programa iconográfico para la decoración escultórica....

acepta los retratos de los Reyes, pero propone que las estatuas de las virtudes que aluden al Rey, sean sustituidas por otras cuatro que reflejen los acontecimientos más destacados de su reinado, sin embargo, respeta las que representan las virtudes de la Reina, adaptándolas más estrechamente a su condición de esposa y madre.

Otra opción sugerida consistía en colocar las imágenes de todos los miembros de la Familia Real, cuyas representaciones deberían hacerse tanto de bulto como en medallones circulares de relieve. Para la balaustrada exterior era partidario de ubicar esculturas de los principales Reyes y Estados de la Corona Española, anticipando lo que se hizo posteriormente. Por último, para la balaustrada del patio, en su afán de buscar temas peculiares de la Historia de España, ofrecía situar personajes ilustres del pasado: Escipión, Aníbal, Pompeyo, Trajano, Teodosio, El Cid, El Gran Capitán, El Cardenal Cisneros, Colón, Hernán Cortés y Alejandro Farnesio. Sobre la puerta principal, debería ir una inscripción latina con el nombre del Rey, que permaneció hasta la colocación de la medalla de la España Armígera, en 1749-50.

\section{Los proyectos del Padre Sarmiento}

Desechadas las memorias presentadas por Olivieri, Sacchetti y el Padre Fèvre, el erudito benedictino pontevedrés, Padre Sarmiento ${ }^{5}$, presentó varias memorias, primero, en 1743 a Felipe V, y, después, en 1747 a Fernando VI. Los «pliegos» donde se expone el sistema de adornos para el Palacio Nuevo, se reparten entre el Archivo General de Palacio ${ }^{6}$, la Biblioteca Nacional, la Academia de Bellas Artes de San Fernando, el Archivo Histórico Nacional y el Museo Británico de Londres.

El sistema de adornos propuesto por el Padre Sarmiento se centró en, Un sistema de adornos dignos de tan magnífica obra y que no desagrade a S. M. Ni concite la censura de los curiosos...; en la más alta y última coronación de las paredes exteriores... se colocarán las estatuas de todos los Reyes de España, como sucedieron unos a otros, desde su primer Rey Ataulpho asta oy, dejando algunos sitios para los futuros. Fernando VI aprobó este plan y el 29 de febrero de 1748 el Secretario de Estado, don José de Carvajal y Lancaster, dirigió una expresiva comunicación al Padre Sarmiento en la que manifestó: $E l$ Rey ha leído literalmente el sistema de ornamentos de escultura que $V$. Rma. ha inventado...se ha servido aprobarlo y aplaudirlo y manda que se ponga en ejecución en todas sus partes. 


\section{$M^{a}$ Jesús Herrero Sanz}

El erudito benedictino había aplicado su vasta cultura literaria e histórica, con paciencia y entrega, a la detalladísima plasmación, en materiales capaces de vencer la acción destructora del tiempo y desplegados sobre los muros de un edificio destinado a durar eternamente, de un mensaje dirigido a las generaciones de un remotísimo futuro, en el que quedase para siempre memoria de las glorias de la Monarquía Hispánica: su entronque con el Imperio Romano; sus soberanos; sus hechos más sobresalientes en lo político, lo científico, lo militar y lo religioso; su vinculación con la Iglesia; incluso, la presdestinación cósmica de su brillante porvenir abocado a la grandeza, al dominio y a la más perfecta armonía en el funcionamiento de su gobierno ?

La idea fundamental de todo el proyecto la señala él mismo: siendo el fundamento y base de todo mi sistema de adornos...La Historia Sagrada de Dios, Salomón, Hiram y la Reina de Saba. Es decir, trató de hacer de todo el sistema interpretativo una gigantesca metáfora que comparaba el Palacio, al menos en su aspecto religioso, con el templo de Salomón puesto bajo el signo de Aries, leído como el Cordero místico, y protegido por la Mujer Apocalíptica.

\section{Estatuas de la Balaustrada}

Para la decoración de este lugar se impuso, finalmente, la serie cronológica de los Reyes españoles, godos, asturianos, leoneses y castellanos. No fue fácil reducir a una sola línea el complejo panorama de las sucesiones, uniones y separaciones de reinos. El Padre Sarmiento se mostraba escéptico acerca de la fidelidad de los retratos existentes de los Reyes anteriores al final de la Edad Media, sin embargo anotó alguna de las series que conocía y que podían servir de orientación a los artistas: la del Salón del Trono del Alcázar de Segovia; la reproducida en la Historia del Padre Mariana, editada en Holanda en 1729; y la que ornamenta la orla del mapa del geógrafo de Felipe V, Nicolás de Fer. La iconografía de las estatuas fue fijada por Sarmiento teniendo en cuenta el perfil histórico de cada Monarca, y combinando elementos simples y comunes: tocado de morrión, corona o diadema; barba larga o corta; escudo a la derecha o la izquierda; calzado abierto o cerrado; espada ancha o cuchillón. Estas indicaciones no fueron seguidas con rigor por parte de los artistas, con el consiguiente enfado del Padre Sarmiento, manifestado en alguno de los documentos.

Repartidas por la geografía española, estas esculturas no han dejado de llamar la atención de viajeros y estudiosos, que las juzgaron de 
muy distinta forma ${ }^{8}$. Alguna vez se cita en el proyecto del Padre Sarmiento que el conjunto de la escultura de Palacio debería formar un enorme libro de mármol en el que el pueblo pudiera aprender a conocer su historia. En junio de 1749 se pidió parecer a los dos directores de escultura, Olivieri y Castro, sobre la forma y material en los que habría de realizarse esta serie de noventa y cuatro esculturas: el material elegido fue la piedra de Colmenar, en vez de mármol, y sobre la ejecución de una vez o varias piezas, se decidió efectuarlas en dos piezas unidas por grapas en la espalda.

Carlos Antonio Bernasconi ${ }^{9}$ fue el encargado de desbastar la mitad de los bloques necesarios, ciento catorce, para las cincuenta y siete estatuas primeras. El ajuste de las esculturas se hizo en varias veces, teniendo en cuenta que las condiciones de ambos dos directores -cantidad de piezas, calidad de las mismas y número de oficiales--, fuesen análogas para evitar rencillas. Primeramente se contrató la ejecución de treinta y cinco estatuas, diecinueve bajo la dirección de Olivieri y dieciséis bajo la de Castro; correspondían a los últimos Reyes de la serie, desde Bermudo III hasta Luis I inclusive, todas ellas se destinaron a la fachada oeste, cuyas obras iban muy adelantadas. Este reparto se hizo antes de que el Padre Sarmiento escribiese sus pliegos dando instrucciones concretas sobre los atributos e iconografía de cada Rey. No ha de extrañar, pues, que sus normas no se siguieran al pie de la letra.

El 6 de abril de 1750 se hizo otro reparto de veintiocho Reyes dirigido por Olivieri, y el 17 del mismo mes otro de veintiuno por Castro. De las ocho que faltan para completar la serie, cinco fueron repartidas sin que conste la fecha exacta y tres quedaron sin identificar ${ }^{10}$. Todas ellas estuvieron colocadas en orden cronológico rodeando el contorno de la planta de Palacio, en sentido contrario al de las agujas del reloj y comenzando por la fachada principal, en el cuerpo saliente denominado «Torre de la Reina», en la línea del Arco de Santiago.

El Padre Sarmiento, el 7 de julio de 1749, propuso que, los cetros, espadas, lanzas y bastones de los reyes se hagan de bronce o latón, y tan bruñido que parezca oro. Pero los adornos no se hicieron. Algunas estatuas llevan cetros de piedra añadidos recientemente. El modelo seguido para estos atributos se tomó de los Reyes del Patio del mismo nombre del Monasterio de El Escorial. Para tener una idea aproximada del efecto que se pretendía lograr, basta con contemplar las estatuas que coronan la fachada principal del Palacio de Aranjuez, realizadas en las mismas fechas. Pedro Martinengo ${ }^{11}$ se encargó de sacar sus bloques, en 1751 . 
El ritmo de ejecución fue rápido. En muchos casos a los artistas se les daba un plazo de tres meses para realizar hasta tres piezas, por tanto, el acabado de las mismas no siempre fue satisfactorio. En junio de 1751 todas las piezas tenían que estar terminadas, puesto que entonces se contrataron las de los ángulos de la planta noble. En esta gigantesca labor colaboró un equipo de casi treinta profesionales, entre los que se encontraban figuras de auténtica categoría: Castro, Olivieri, Dumandré, Michel, Álvarez, Mena y Salvador Carmona, cuyos trabajos destacan por encima del resto, junto a otros que apenas habían sobrepasado el nivel de oficiales de cantería. El precio que se pagó por cada una de ellas fue el mismo: once mil reales.

Actualmente sólo podemos contemplar en su lugar original algunas esculturas. El 8 de septiembre de 1760, Carlos III dio la orden de bajar y almacenar las estatuas. Son varias las hipótesis formuladas para explicar esta decisión, descartándose la de amenaza para la seguridad del edificio, aunque muchas veces se le reprochó a Sacchetti el excesivo grosor de los muros y la solidez exagerada del mismo. Más bien debe insistirse en el cambio de gusto del nuevo Monarca, que va abandonando la pompa ornamental del tardo barroco para dejar paso a la austera limpieza del neoclasicismo ${ }^{12}$. La orden del Rey fue comunicada a Elgueta, Intendente de las Obras de Palacio, por el Marqués de Esquilache en estos términos: El Rey manda que se quiten del nuevo real Palacio todas las estatuas que están en la circunferencia de sus cuatro fachadas, tanto sobre la cornisa superior de su fábrica como las del medio de ella y que se depositen y guarden por ahora en las piezas inferiores del mismo Palacio que parecieron $a$ V. S. más a propósito para el intento, en el interin que S. M. delibera situarlas en otro paraje más decente ${ }^{13}$. A partir de 1787, fueron saliendo de los almacenes, paulatinamente, para ser colocadas en diferentes ciudades y puntos de España, cuyos ayuntamientos las solicitaban para embellecer sus calles y paseos: Madrid, Burgos, Vitoria, Pamplona, Toledo, Logroño, cuentan con esculturas procedentes del Palacio Nuevo ${ }^{14}$.

\section{Estatuas del Piso Principal}

En los ángulos de los muros, al nivel de la planta noble, existían catorce pedestales de planta casi circular y de altura semejante a la de los plintos y basas de las columnas, donde Sacchetti había previsto colocar trofeos de guerra de bulto redondo. Desechado el plan del arquitecto, el religioso benedictino ideó representaciones más adecuadas. 
En un primer momento se juega con el número doce: los trabajos de Hércules, los meses del año, los signos del Zodíaco, los dioses del Olimpo, etc, pero fiel al criterio de vincular la Historia de España con símbolos de carácter universal, se inclinó por colocar héroes o Reyes Españoles. Tras descartar cuatro ternas de Reyes y condes de Galicia, Aragón, Navarra y Castilla, terminó por elegir parejas de Monarcas, y así dar cabida a Portugal en homenaje a la Reina Bárbara de Braganza, y a los caudillos de la América conquistada como Moctezuma y Atahualpa. De esta forma se contaba con doce personajes a los que se unieron, para los ángulos de la capilla, San Millán de la Cogolla y Santiago, particularmente queridos por el Padre Sarmiento como gallego y benedictino ${ }^{15}$.

Una vez elegidos los personajes, el 2 de junio de 1751, se dictaron las normas sobre su iconografía, indumentaria y fuentes en las que los escultores tenían que buscar información gráfica. Moctezuma, una de las piezas más bellas del conjunto, parece derivar de la representación de América, hecha por el francés Thierry, para los jardines de San Ildefonso; para el rey Juan $\mathrm{V}$ de Portugal se usó como modelo un retrato de Ranc; y para los condes de Castilla, las pinturas del Arco de Santa María de Burgos. Como estas esculturas estarían más al alcance de la vista que las de la balaustrada, se puso especial interés en su acabado. Olivieri y Castro dieron, cada uno, siete nombres para adjudicar las esculturas, cuyos artífices trabajaron bajo la dirección del maestro. Pedro Martinengo fue, de nuevo, el encargado de sacar y suministrar las piedras para las esculturas y el precio en el que se tasó cada una se estimó en unos 15.000 reales, según la calidad de las mismas. La mayoría quedaron por debajo de esta cifra y solo una, Juan V de Portugal ejecutada por Salvador Carmona, rebasó el precio establecido de 18.500 reales. Sufrieron los mismos cambios que las esculturas de la balaustrada, pero en 1972 se volvieron a colocar en el piso principal, donde actualmente se contemplan ${ }^{16}$.

\section{Los Emperadores Romanos}

Son las únicas esculturas que han permanecido siempre a la vista en Palacio, aunque tampoco se ubican en su emplazamiento original, puesto que sólo permanecieron seis años en su lugar de origen: sobre las cuatro columnas que sustentan el balcón principal. El Padre Sarmiento al idear estas efigies, tuvo presentes los Reyes del Patio de Entrada a la Basílica del Monasterio de El Escorial: tengo idea de 


\section{$M^{a}$ Jesús Herrero Sanz}

que en la entrada de la iglesia del Escorial hay imágenes de Reyes sagrados. Por no repetir, y por la similitud, me parece vendrían bien en la entrada de un Real Palacio cuatro estatuas de Emperadores españoles, colocadas en las cuatro basas que están ya prevenidas. Digo pues, que deben efigiar cuatro estatuas atlánticas, o de estatura de coloso, que representen a los cuatro Emperadores romanos, y españoles de nación, en la disposición siguiente: Arcadio, Trajano, Theodosio y Honorio ${ }^{17}$.

El 16 de junio de 1751 se hizo el reparto de estas obras: para Olivieri las esculturas de Honorio y Teodosio, y para Castro las de Trajano y Arcadio. Surgieron diferencias entre estos dos maestros en cuanto a la calidad de la piedra que se proporcionó a uno y a otro, Castro se quejó diciendo: A Olivieri como tengo ciertas noticias se le sacaron las mejores piedras que ha habido en la cantera; a mí, no sólo no me las sacaron buenas, pero ni me las han querido sacar, y así, o ha de ser con armas iguales la competencia o no la puedo admitir ${ }^{18}$. Así pues, en este ambiente de tensa rivalidad, Olivieri y Castro trabajaron sus esculturas poniendo en ellas toda su habilidad y todo su talento. A través de la documentación sabemos que todavía no estaban terminadas en 1753, al menos las de Castro, que el 23 de abril de ese año todavía percibió dinero a cuenta por ellas.

Las monedas antiguas y los bustos de emperadores romanos que adornaban algunas estancias del antiguo Alcázar o jardines como los de Aranjuez, sirvieron de inspiración para realizar estas esculturas. A ello hay que añadir los conocimientos adquiridos por los propios escultores durante su período de aprendizaje. Es evidente la semejanza entre la coraza del Trajano de Felipe de Castro, y la de la estatua colosal de Constantino en el nártex de San Juan de Letrán, donde Castro trabajó con Filippo della Valle ${ }^{19}$.

Estas esculturas destacan por su finura, maestría y acabado en comparación con el resto, especialmente, con las del cornisamento. Actualmente se encuentran colocadas en el Patio del Príncipe bajo cuatro arcos. Las dos de Castro en el lienzo norte, lugar privilegiado al estar frente a la entrada, donde reciben luz, las de Olivieri en el lienzo sur. Quizá se consideraron mejores las del escultor español.

\section{Los Reyes Legendarios y Los Héroes Mitológicos}

Sobre cada uno de los frentes de las cuatro torres, Sarmiento proyectó una serie de personajes, que acentuarían, aún más, la armonía general del conjunto. Los personajes elegidos fueron cuatro Reyes legendarios 
Programa iconográfico para la decoración escultórica....

de España, de los citados en las fuentes más antiguas, y cuatro dioses o héroes remotísimos que fueron adorados o famosos en nuestra patria. Los dioses irían en las fachadas norte y sur, y los Reyes en las de este y oeste en la forma siguiente. Fachada sur: Hércules y Osiris; fachada norte: Endovélico y Netón; fachada este: Habidis y Gárgoris; Fachada oeste: Gerión y Argantonio. De nuevo serán las monedas ibéricas de la Real Biblioteca la fuente de inspiración para la representación. En este caso se siguieron al pie de la letra las instrucciones del Padre Sarmiento y como no podían hacerse de cuerpo entero, se fabricaron bustos cuya silueta se recorta airosamente contra el cielo. Debajo de cada uno aparecen una serie de trofeos que se corresponden con el origen y cualidades de cada héroe: bajo Hércules las dos columnas en forma de aspa y una piel de león; bajo Netón, asimilado a Marte, dios de la guerra, una honda, un martillo, una flecha y un carcaj; bajo Gerión, considerado rey de Tartessos y personificación del mismo río, el rostro de un buey y un perro, pues también fue pastor de bueyes; bajo Habidis, el rey que enseñó el arte de la agricultura, un arado y un manojo de espigas; bajo Gárgoris, descubridor de la apicultura, un panal con cuatro abejas volando; bajo Endovélico, dios lusitano asociado al amor, un arco y unas flechas como Cupido; bajo Argantonio, delfines cruzados y un martillo; bajo Osiris elementos relacionados con la agricultura ${ }^{20}$.

El diseño de estas piezas se debe a Olivieri y sus autores fueron Pedro Lázaro, Miguel Jiménez y Pedro Martinengo, quienes se obligaron a executar de mano y de piedra blanca los cuatro trofeos para los frontis de las torres de Rey y reina en 1.200 reales cada uno. Estos ocho bustos no sufrieron el desalojo de 1760 , se respetaron y quedaron aislados del resto de las esculturas. Sin embargo, uno de ellos desapareció al construirse el ala oriental de la ampliación prevista por Sabatini: se trata del busto de Osiris, que aparece en el cuadro de Brambilla titulado, Vista de la fachada principal del Real Palacio de Madrid ${ }^{21}$.

\section{El adorno de las fachadas}

El aspecto actual de la fachada sur o fachada principal de Palacio es fruto de un largo proceso, aunque ya desde 1747, el Padre Sarmiento tuviese clara su decoración. Cita los cuatro emperadores nacidos en España y luego añade: En el nicho medio, entre Trajano y Theodosio, y superior a ellos, se debe colocar, o en estatua, o en relieve, una matrona 
majestuosa que represente a España, o según la pintaron los romanos puramente, o añadiendo a esa pintura algún nuevo adorno, y no sería impropio que tuviese un timón en su derecha y que el timón rodase entre dos globos, o dos mundos, puestos al pie, y el texto de Claudiano hablando de España Contulit Augustos o el inmediato Haec generat qui cuncta regant, o el antecedente Principibus foecunda piis.

La preferencia del Padre Sarmiento por Claudiano es patente a lo largo de sus escritos. Este poeta latino había nacido en Alejandría, pero vivía en Roma, y en su Laus Serenae, escrito hacia el 404, hace un canto de España de donde están tomadas las citas propuestas para las inscripciones. En el poema exalta la riqueza del país en caballos, frutas y metales y también alude a los emperadores que habían nacido en España. Las palabras de Claudiano fueron fielmente reproducidas en piedra, y así, en el relieve de la fachada sur aparece la representación de España, dividida en dos partes. La parte superior tiene una «medalla» ovalada con el relieve de España encarnada por la figura de una matrona sentada rodeada de atributos de guerra, armada con coraza y casco, y portando en la mano izquierda una lanza de hierro, que es a la vez caduceo de Mercurio por las serpientes enroscadas en ella; con la mano derecha sostiene un timón que parece apoyarse en dos hemisferios representados sólo en parte; a los pies hay un conejo, alusión a la supuesta etimología fenicia de España, país de conejos, y en la banda que sirve de pedestal y cierre de la composición la leyenda, Pretiosa metallis. Bajo la España armigera y Gobernatriz, como se cita frecuentemente en los documentos, una figura masculina, desnuda y barbada, se recuesta sobre un cuerno del que brotan monedas; tras él aparecen dos ovejas, un toro y un caballo; con la mano izquierda levantada, el hombre parece señalar a la figura femenina que está sobre él ${ }^{22}$. Este conjunto ocupa la altura del entresuelo y parte del segundo piso; está enmarcado por una moldura mixtilínea que incluye dos volutas adornadas con guirnaldas de flores y frutos y rematada por un frontón incompleto que se apoya en dos mútulos. En la parte inferior de esta moldura van las frases de Claudiano antes citadas ${ }^{23}$. La medalla elíptica es de un solo bloque, la alegoría de la parte baja, de dos, y el material utilizado, mármol blanco de la Sierra de Macael. Los relieves los hizo personalmente Olivieri para ser colocados el 24 de agosto de 1751. La tasación de la obra se le encarga a Castro, que trató con dureza a su compañero, diciendo que, si no estuvieran llenas de remiendos merecería el Artífice treinta mil reales de vellón; pero habiendo yo notado que la, figura de la España tiene cuatro grandes remiendos: que son toda la cabeza con el cuello, y parte del pecho; los dos brazos 
del codo adelante y el cabo del timón o governalle..., digo que merece once mil rs. de vellón ${ }^{24}$.

Tras varios proyectos y discusiones, se optó por colocar sobre la medalla un Zodíaco recorrido por el sol en torno a un león coronado. La decoración constaba de dos partes bien diferenciadas: una de relieve con la representación de un arco sembrado de estrellas con un sol en el centro y un castillo coronado debajo, que prolongaba los dos paneles laterales; y sobre este relieve de fondo, una segunda parte de bulto redondo con un león en actitud de reposo, aprisionando un globo terráqueo entre sus patas delanteras, cargado con los atributos de la realeza y las columnas de Hércules con la leyenda, Plus Ultra, grabada. El león fue ejecutado por Castro en piedra de las canteras de San Agustín, de una sola pieza, y fue colocado en el ático el 4 de octubre de 1752. Pero al igual que piezas anteriores, duró poco en el lugar para el que fue pensado, porque el 21 de marzo de 1764 se bajó de la fachada. De todo ello hay documentos gráficos y su destino final pudo ser la cabecera del Canal del Manzanares, si nos atenemos al grabado que ilustra el Diccionario de Madoz, en el que también aparecen las columnas. El paradero áctual, como otras muchas piezas, es desconocido, a pesar de que son muchos los estudiosos que no desesperan en localizar estas obras de $\tan$ complicada y curiosa historia ${ }^{25}$.

La bajada del león significa un paso más en el despojo al que fue sistemáticamente sometido el Palacio en los primeros años del reinado de Carlos III. El móvil inmediato fue el deseo de instalar el reloj que hoy podemos ver en este lugar. Este reloj estaba en el Palacio del Buen Retiro y el encargado de su traslado al Palacio Nuevo fue Guillermo Boiston.

Para la fachada norte, donde se sitúa la Capilla, el Padre Sarmiento eligió como fuente de inspiración el Apocalipsis de San Juan y el signo de Aries, en alusión al Cordero Místico, en vez del león que representaba la Monarquía en el paño sur. Esta fachada tenía un carácter eminentemente religioso, $y$, al colocar este adorno, se exaltaba la figura de Cristo, comparándola al sol, que, por otra parte, era señal de Justicia. Ambas fachadas debían tener un paralelismo, y, si en la sur estaba la medalla de la España Armígera, en la norte iría una medalla de la Virgen acompañada de los dos copatronos de España, San Andrés y Santiago. El relieve del Cordero Místico fue diseñado por Olivieri y realizado en piedra de Colmenar: se representa un cordero sobre un libro de siete sellos y siete ojos, estrellas y otros adornos como una lira a la izquierda, un vaso de perfumes a la derecha, el sol, el zodíaco y ráfagas. En 1753 estaba concluido. Para la medalla de la 
Virgen se eligió mármol de Badajoz, y para los relieves de San Andrés y Gedeón la piedra de Colmenar.

La elección de estos dos santos no es gratuita: ambos personajes están vinculados con la Orden del Toisón de Oro, fundada por Felipe el Bueno de Borgoña, y relacionados, a su vez, con el Vellocino de oro. San Andrés, como santo patrono de Borgoña, lo fue automáticamente de la Orden, y las grandes reuniones solemnes de la misma se celebraban el día de su festividad, 30 de noviembre; aparece en pie con la cruz en aspa, característica de su martirio. En cuanto a Gedeón, uno de los jueces hebreos, es muy conocida la historia de los milagros realizados con una piel de cordero; aparece en pie, con una pequeña vasija en la mano derecha, mientras que con la izquierda sujeta una piel de cordero; a sus pies un altar adornado con el collar del Toisón y un cordero encima. Estos relieves se venían atribuyendo a Pablo Martínez y Antonio Dumandré, pero investigaciones actuales asignan el San Andrés a Alonso de Grana, que, en 1753, recibió un libramiento para terminar de pagarle los 7.500 reales que importa la obra de piedra blanca de Colmenar de Oreja, que ha ejecutado para la misma fachada. Sin embargo no hay libramientos referentes al Gedeón de Dumandré, aunque cobró la misma cantidad en esta fecha, y ambas son análogas en tamaño y técnica. Se tasaron a la vez en la misma suma por Olivieri y Castro ${ }^{26}$. El encargo de la medalla de la Virgen se le hizo a Castro, en 1749, y el mármol elegido fue el de Badajoz. En 1758 todavía no se había hecho nada, e, incluso, se cambió el escultor escogido, asignándole a Olivieri su ejecución, pero no se esculpió nunca.

Como remate de la cúpula de la Capilla de Palacio el Padre Sarmiento había previsto colocar una estatua ecuestre de Santiago, en bronce. La documentación sobre este asunto es bastante copiosa, sin embargo, no llegó a realizarse. De nuevo fue Olivieri el encargado de elaborar el diseño y con ello se pretendía ofrecer la visión de uno de los episodios más notables de la Reconquista española con la batalla de Clavijo. La silueta de este grupo, lamentablemente eliminado, recortada sobre el cielo y dominando el conjunto de la Capilla, conseguiría un impacto decorativo difícil de igualar. Los arquitectos desaconsejaron poner este adorno por razones de peso, $\mathrm{y}$, al final, la cúpula se remató por una bola y una cruz de bronce dorado, en cuya peana se labraron cuatro cabezas de león y ocho festones en piedra blanca.

En todas las fachadas se mandaron esculpir escudos sostenidos por grifos en piedra de Tamajón, localidad próxima a Cogolludo (Guadalajara), que, al ser de calidad muy fina, con frecuencia se le llama mármol en los documentos. Al final se realizaron en piedra de Colmenar, 
a pesar de que se habían sacado ya las piezas precisas para ellos. Las armas grabadas en estos escudos son las del Rey Fernando VI, que ocupaba entonces el trono de España: las lises de los Borbones están rodeadas por un doble collar, el de la Orden del Espíritu Santo y el del Toisón de Oro, colocados sobre una espadaña o peineta que sobresale por encima de la balaustrada. El de la fachada de oriente cobra una mayor prestancia por su riqueza en atributos militares y por los dos grifos que lo escoltan en actitud rampante. Los diseños de los escudos fueron realizados por Olivieri y la ejecución corrió a cargo de un equipo numeroso de tallistas, donde se encontraban Diego Martínez, Pedro Martinengo, Silvestre Soria, Lucas del Corral o José Pérez, que los tenían terminados en marzo de 1750. El de la fachada de occidente, colocado entre leones y palmas, se hizo un año antes, en 1749 , ya que esta parte del edificio iba más adelantada ${ }^{27}$.

\section{Otras piezas de escultura decorativa}

Los huecos del piso principal, con excepción de los tres centrales del sur y el del medio de la fachada norte, están cobijados por frontones alternados en cuyos tímpanos se alojan adornos de escultura consistentes en cabezas de máscara, en los triangulares, y veneras, en los curvos. Comenzaron a hacerse en piedra de Tamajón, pero, en 1744 , se decidió que este material no era lo bastante noble y que habrían de ser de mármol de Urda. Se necesitaban cuarenta y dos cabezas para los frontones triangulares y treinta y ocho conchas para los curvos. Finalmente se hicieron en piedra de Colmenar y se pagaron a 1.020 reales cada pieza. Se ajustaron, en 1746, conservándose referencias exactas de su número y medidas, de los escultores que las realizaron, y de la cantidad hecha por cada uno. Dumandré, Boiston, Carmona, Grana, Olivieri, Villanueva o del Corral son algunos de los escultores que realizaron estos adornos ${ }^{28}$.

Para el aumento del ala sur de Sabatini se necesitaron diez conchas y diez máscaras más, realizadas por el escultor Manuel Adeva Pacheco, que las terminó de cobrar en 1781. En la fachada sur, sobre la balaustrada superior, podemos contemplar catorce jarrones adornados con flores que fueron diseñados por Sacchetti y esculpidos por Miguel de Jeregui, Silvestre de Soria, Diego Martínez y Juan Bautista, que fueron pagados el 16 de julio de 1749 por catorce jarrones de la referida piedra blanca de Colmenar para la sobrebalaustrada ${ }^{29}$. En algunas de las claves de los arcos, distribuidos por todo el edificio, podemos 
ver el elemento decorativo predilecto del arquitecto de palacio: cabezas de león. Fueron diseñados por Olivieri y realizados entre 1746 y 1747 según las cuentas de dichos años.

Los relieves de la galería

En los pliegos firmados el 30 de agosto de 1747, el Padre Sarmiento expone una vasta concepción para el adorno de los cuatro paños de la galería, en torno al patio. Cada uno de ellos tiene un significado general, que después detalla y matiza en temas concretos. El lado sur es el lado político, porque en él se encuentra el salón de Embajadores y el Balcón Principal con su decoración alusiva a la gloria de la Monarquía Española. El lado norte es el lado religioso, porque en él se ubica la Capilla y la representación del Cordero Místico como triunfo de la Iglesia. Los lados este y oeste son los militar y científico, respectivamente, sin que haya razones tan visibles que lo justifiquen. A cada uno de estos lados se abren once huecos con sus espacios reservados para relieves, y frente a ellos los nueve correspondientes a los arcos que se abren al patio ${ }^{30}$.

De los cuarenta y cuatro huecos proyectados en principio, quedaron, después, treinta y siete, ya que se suprimieron las sobrepuertas de la Capilla. El trabajo estaría dirigido por Olivieri, que diseñó las formas que habían de tener los relieves; el material elegido fue el mármol de Badajoz, aunque en algunas ocasiones se utilice el de Valencia. El programa iconográfico fue seguido al pie de la letra y el lugar donde se labraron fue la Casa de Rebeque, cercana al Palacio ${ }^{31}$.

El 31 de julio de 1752 se pidió a Olivieri que hiciera el reparto de las medallas, como se denominan en los documentos. Los escultores se eligieron entre los mismos que habían trabajado en las estatuas de la balaustrada. Los relieves se fueron ejecutando a partir de esas fechas con lentitud, por lo que a la llegada de Carlos III no estaban hechos todos. El nuevo Rey ordenó que se recogieran todos los relieves, incluso los no terminados, y que la labor se detuviera por completo. Carlos III quería un Palacio con la menor cantidad posible de escultura monumental. El 14 de septiembre de 1760 los escultores recibían la orden de no trabajar más en ellos. Sabatini proponía que los relieves sin terminar fueran rematados por Olivieri y Castro que, al mostrar su disconformidad y resistencia, recibieron amenazas de supresión de sueldo. 
Se pensaba que, aunque no se colocasen en el lugar previsto, una vez acabados por los escultores principales, podría encontrarse un nuevo destino para ellos. Pero Olivieri murió sin que se hubiera tomado una última decisión y Castro olvidó por completo el encargo. En general los relieves acusan diferencias en su ejecución y técnica, dado que fueron muy distintos los autores que los realizaron. Son muy característicos los anacronismos en la indumentaria. Hay algunos de hábil ejecución y movimiento elegante, como los de Carlos de Salas o Roberto Michel, pero en la mayoría la composición es monótona y convencional. Algunos tienen un cierto interés iconográfico como el que representa la Toma de Toledo, de Huberto Dumandré, por la vista de la ciudad, - la Alegoría de la Música, de Antonio Dumandré, en el que los personajes asomados a un balcón en último término a la derecha, pudieran ser retratos de miembros de la Familia Real. El relieve de La batalla del Salado ofrece una habilidad superior para la gradación de los términos; fue ejecutado por Felipe de Castro, y se guarda en la Academia de San Fernando.

Actualmente, de los relieves completos e inacabados, se conservan veinticinco en el Museo del Prado, algunos expuestos en las salas del piso alto dedicadas a la pintura del siglo XVIII, llegados en 1862; y seis en la Sala de Juntas de la Academia de Bellas Artes de San Fernando, colocados en 1928. A pesar de sus deficiencias y particularidades, si se hubieran situado en su lugar original, la serie habría conferido mayor riqueza al ambiente de la galería. A la altura de las sobrepuertas, siempre resultarían vistosos, y la galería alcanzaría un realce decorativo del que carece en la actualidad. El ideal de la creación artística propuesto por la Academia se manifestó de forma expresiva en estos relieves. A fin de cuentas, los temas de los ejercicios de los concursos que se celebraban con periodicidad no diferían esencialmente de los utilizados aquí: estampas de la Historia de España evocadas a través de los prejuicios del ambiente en que se estaba gestando la aparición del Neoclasicismo.

\section{Notas}

1 Sobre este aspecto, se puede consultar la tesis de TÁRRAGA BALDó (1992): vol. III, 17-19.

\footnotetext{
2 Plaza SANTiago: 105.

3 SÁNCHEZ CANTÓN. (1956).

4 BotTineau: 534-36.
} 
5 Pedro José García de Balboa es conocido por su nombre de religión, Fray Martín Sarmiento, adoptado al profesar en la Orden Benedictina, el 24 de mayo de 1710 .

6 Conrado Morterero. (1972).

7 Plaza Santiago: 110.

8 El primer estudio monográfico dedicado a estas esculturas fue el de don Elías Tormo: 189-204.

9 Plaza Santiago: 195.

10 Plaza Santiago: 197, elabora un listado de las esculturas dando las atribuciones y autorías de las mismas. Así mismo identifica las tres que no recogió Varón Vallejo.

11 TÁRRAGA BALDÓ. (1976): 435-352.

12 Plaza Santiago: 203.

13 MORTERERO: 68.

14 Plaza SANTiago: 209-212, hace un exhaustiva relación de dónde se encuentra cada figura.

15 Plaza Santiago: 220, realiza un esquema con la disposición de las esculturas.

16 ANDRADA: 49-56.

17 Plaza Santiago: 222, nota 4.

18 Plaza SANTiago: 223.

19 MELENDREAS Jimeno y TÁRRAGA. (1992), vol. III, 248-271.

20 Endovélico y Argantonio están cambiados de lugar, pues Argantonio se representa como joven imberbe y Endovélico como rey anciano y con la cabeza cubierta con un casco.

21 Este cuadro se conserva en el Palacio de la Zarzuela y tiene el $\mathrm{n}^{0}$ de inv. 10055556. Actualmente en el lugar de Osiris se encuentra una reproducción del busto de Juanelo Turriano (1500-1585), relojero del Emperador Carlos V, conservado en el Museo de Santa Cruz de Toledo. El busto original fue restaurado por el escultor toledano Cecilio Béjar (+ 1971) tras la guerra civil, y a él se debe la reproducción de Pala-cio, colocada en 1987. Sobre este busto, consultar el artículo de CAMPO Y FRANCÉS: 79-96.

22 En los textos modernos de este personaje se le designa habitualmente como el río Tajo. La abundancia de referencias en los versos de Claudiano a las auríferas arenas arrastradas por el río justificaría la representación de éste sobre una cornucopia de la que brota un chorro de monedas de oro. También se le ha identificado en algunos documentos como el dios Plutón, dios del subsuelo y de los muertos.

23 La traducción de las inscripciones sería: «Rica en Metales» «Produjo Emperadores, Engendra a quienes rigen todas las cosas». De esta forma se establece el lazo de unión entre esta decoración y las estatuas de los Emperadores que custodiaban la puerta de entrada al Palacio.

24 Plaza SANTiago: 229-30 y TÁRraga, (1992): 187-192.

25 Plaza SANTiago: 239-47.

26 TÁRraGA. (1992) lo da por seguro de Dumandré, 237.

27 TÁRRAGA. (1992): 127-32.

28 TÁRRAGA. (1992):, 24 y 119.

29 Plaza SANTiago: 263.

30 Todo lo referente a los temas y distribución de estos relieves lo encontramos en el artículo de LORENTE JUNQUERA Y PlazA SANTIAGO: 180-188.

31 TÁRRAGA. (1992): 2, 41-52. 


\section{Programa iconográfico para la decoración escultórica....}

\section{Bibliografía}

AndRadA, R. (1972): "Doscientos años después, las estatuas del Palacio de Oriente vuelven a su sitio". Reales Sitios 31, 49-56.

BÉdat, C. (1971): El Escultor Felipe de Castro. Santiago de Compostela. Instituto Padre Sarmiento.

Blanco, A. y Lorente, M. (1969): Museo del Prado. Catálogo de la Escultura. Madrid. Gráficas Cóndor, S.A.

Bottineau, Y. (1986): El arte cortesano en la España de Felipe V (1700-1746). Madrid. Fundación Universitaria Española.

Campo y Francés, A. del (1996): «Juanelo Turriano relojero de Carlos V e ingeniero de Felipe II. El busto de Leoni y la medalla de Trezzo". IX Jornadas de arte. El arte en las colecciones de Carlos $V$ y Felipe II. CSIC, 79-96.

GARCÍAGAINZA, M. C. (1990): El escultor Luis Salvador Carmona. Universidad de Navarra.

LoREnte Junquera, M. (1954): "Los relieves marmóreos del palacio Real de Madrid». Arte Español T. XX, 58-71.

MADOZ; P. (1845): Diccionario geográfico-estadístico-histórico de España y sus posesiones de ultramar. Madrid. Tip. P. Madoz Sagasti.

Martín González, J. J. (1990): Luis Salvador Carmona. Escultor y académico. Madrid.

MelendReras Jimeno, J.L. (1987): «Las esculturas de los emperadores romanos: Trajano, Theodosio, Arcadio y Honorio". Reales Sitios 93, 73-75.

Morterero, C. (1972): «Documentos del Padre Sarmiento para el adorno exterior del Palacio Real de Madrid». Reales Sitios 31, 57-68.

Plaza Santiago, F. J. de la (1975): Investigaciones sobre el Palacio Real Nuevo de Madrid. Valladolid. Departamento de Historia del Arte. Universidad de Valladolid.

Ponz, A. (1793): Viage de España. Madrid. Por la viuda de D. Joaquín Ibarra. Tercera Impresión.

Sánchez Cantón, F. J. (1956): Opúsculos gallegos sobre Bellas Artes en los siglos XVIII y XIX. Colección Bibliófilos Gallegos III. Compostela.

Sánchez Cantón, F. J. y Pita Andrade, J. (1948): Los retratos de los Reyes de España. Barcelona.

TAMAYO, A. (1946): Las iglesias barrocas madrileñas. Madrid.

TÁrRAga BALdó, M. L. (1976): “El escultor Pedro Martinengo y la fachada principal del Palacio de Aranjuez». Archivo Español de Arte 196, 435-452.

IDEM, (1992): Giovan Domenico Olivieri y el taller de escultura del Palacio Real. Madrid. 3 vol.

Idem, (1992): "La "Casa de Rebeque" o Casa-Taller de Escultura». Anales del Instituto de Estudios Madrileños, T. XXXI, 41-52.

Tormo, E. (1916): Las viejas series icónicas de los Reyes de España. Madrid. Blass y Cía.

VARón VALLEJo, E. (1931): “Los proyectos del padre Sarmiento sobre la decoración escultórica del Real Palacio Nuevo de Madrid y estatuas de la balaustrada exterior». Archivos, Bibliotecas y Museos T. 52, 101-119. 


\section{$M^{a}$ Jesús Herrero Sanz}

Arcadio. Felipe de Castro. 1750.

Patio del Príncipe

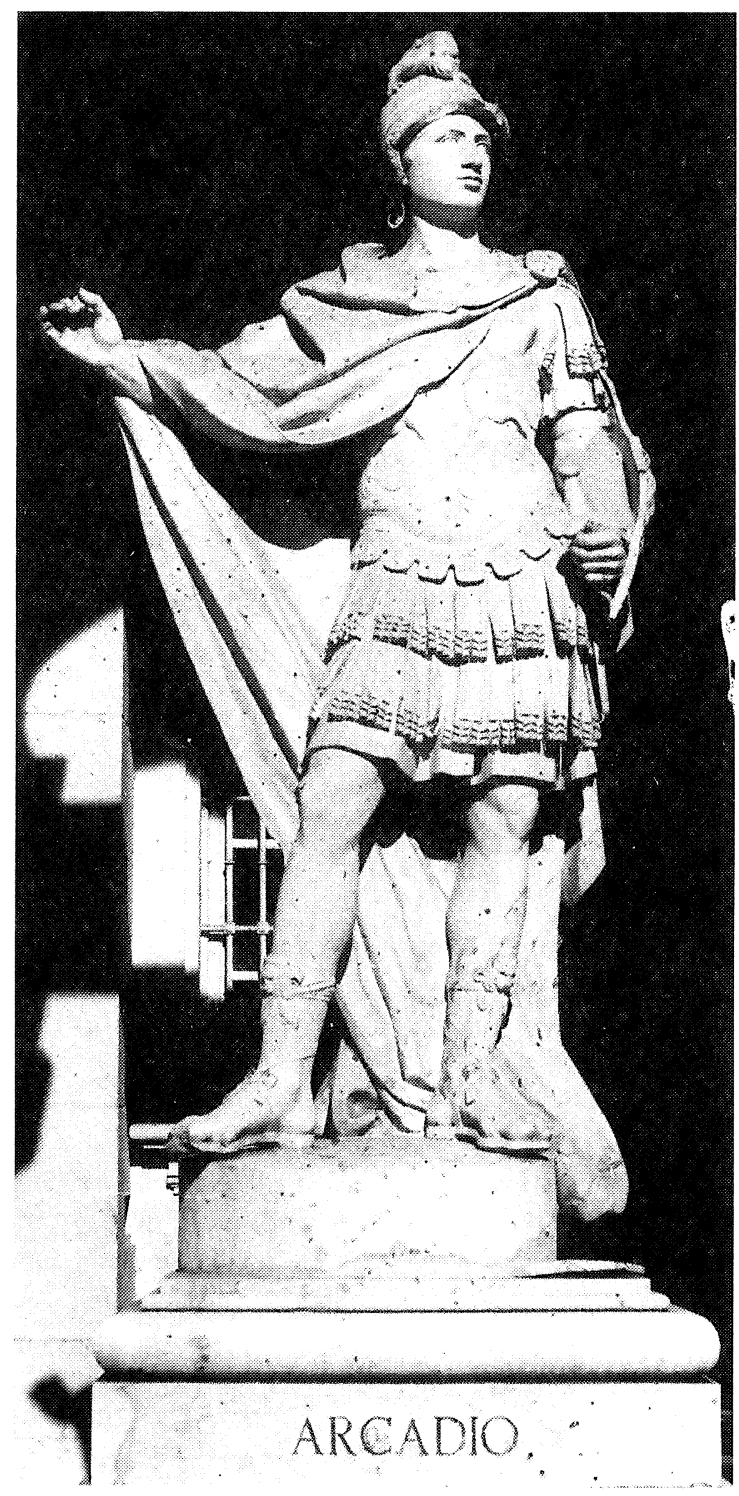


Programa iconográfico para la decoración escultórica....

Juan V. Luis Salvador Carmona. 1751.

Fachada principal

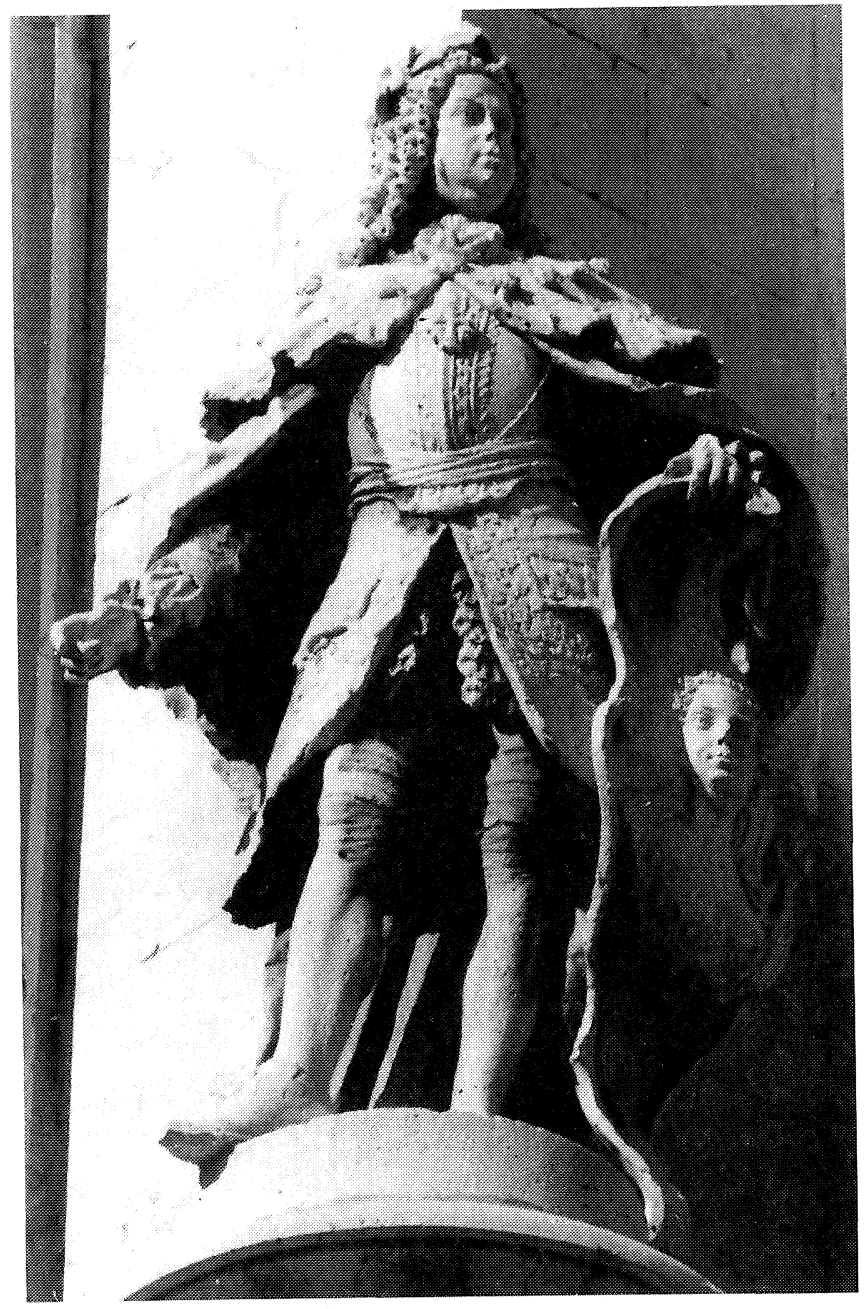




\section{$M^{a}$ Jesús Herrero Sanz}

Honorio. Juan Domingo Olivieri. 1750.

Patio del Príncipe

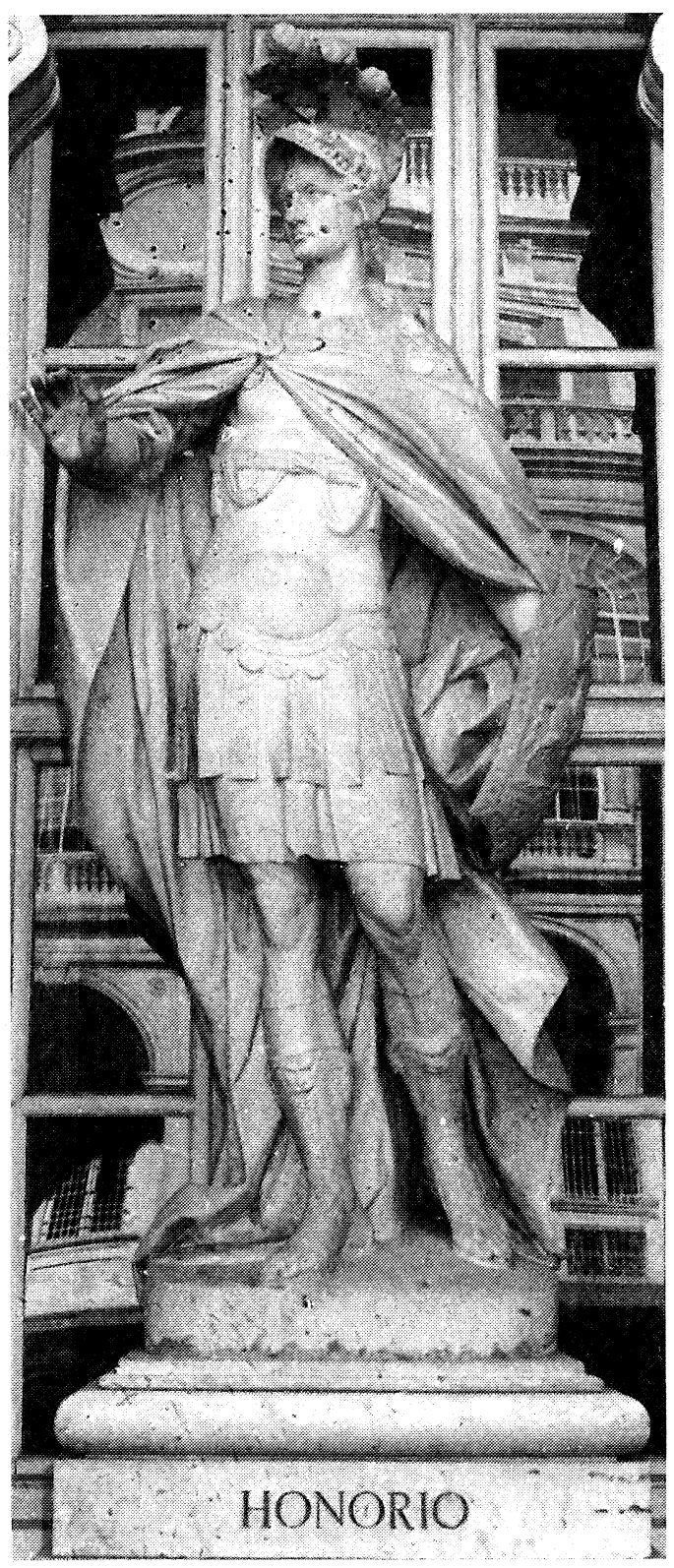




\section{Programa iconográfico para la decoración escultórica....}

Atahualpa. Domingo Martínez. 1753.Fachada-Armería sur

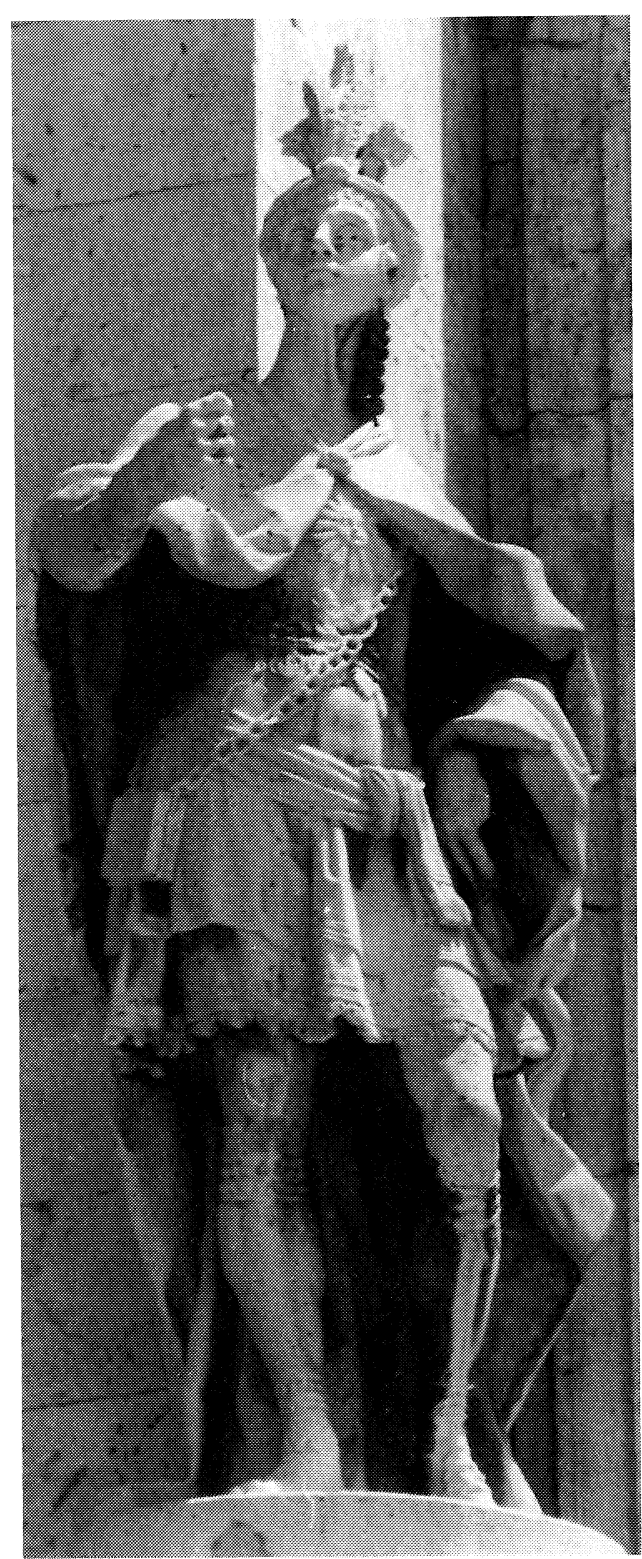




\section{$M^{a}$ Jesús Herrero Sanz}

50

Felipe V. Juan domingo Olivieri. C. 1750.

Fachada de la Armería

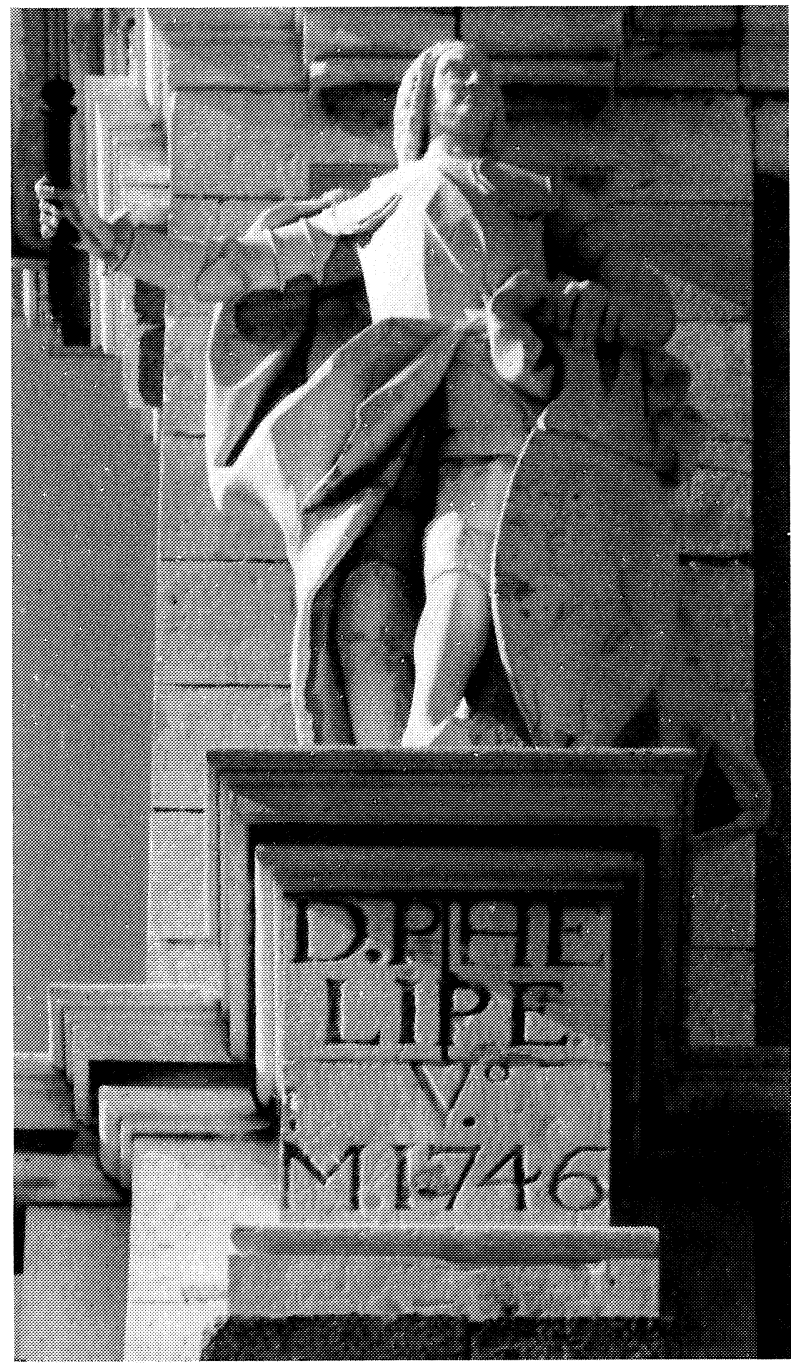




\section{Programa iconográfico para la decoración escultórica....}

Moctezuma. Juan Pascual de Mena. 1753. Fachada Armería sur

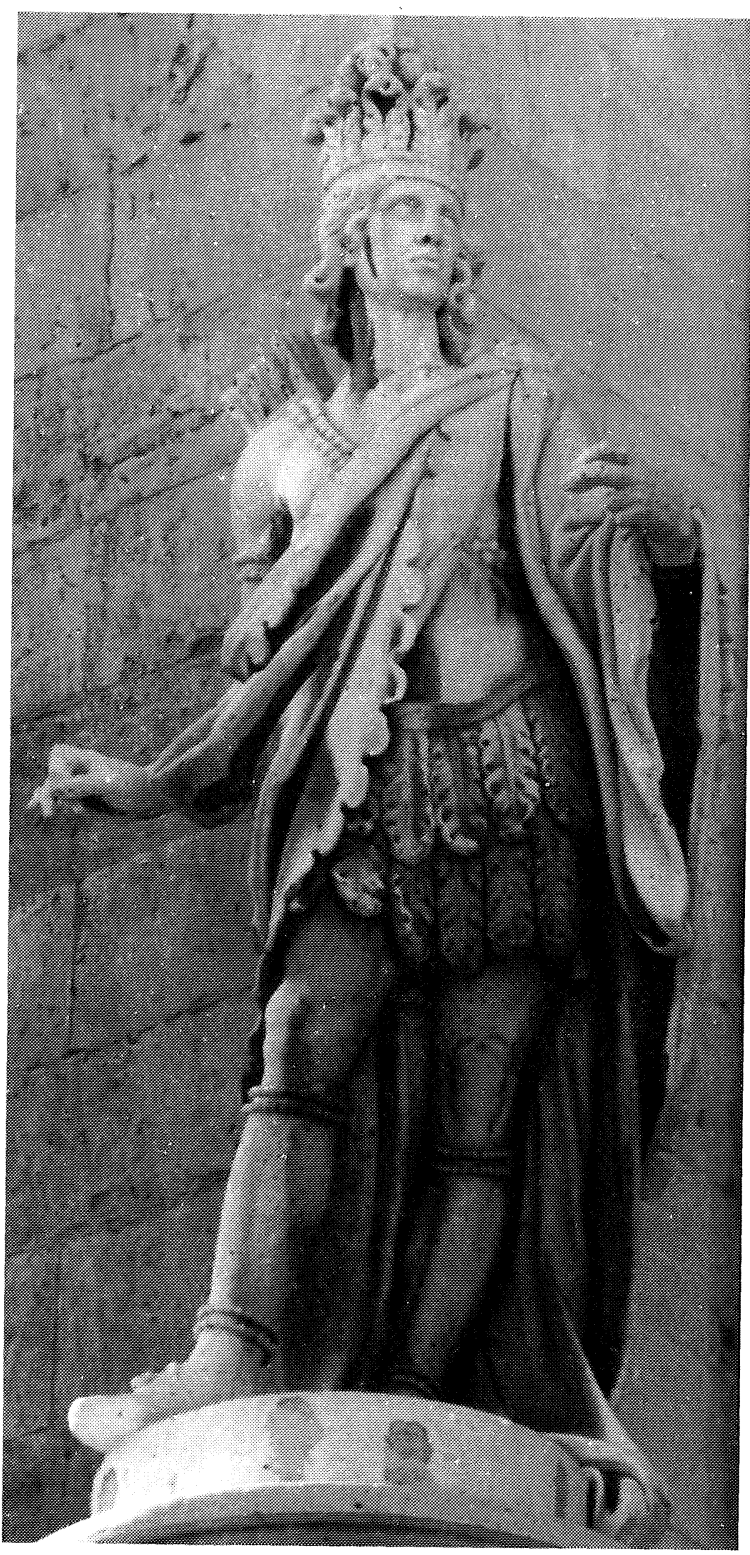




\section{$M^{a}$ Jesús Herrero Sanz}

52

Habidis. 1750. Fachada este

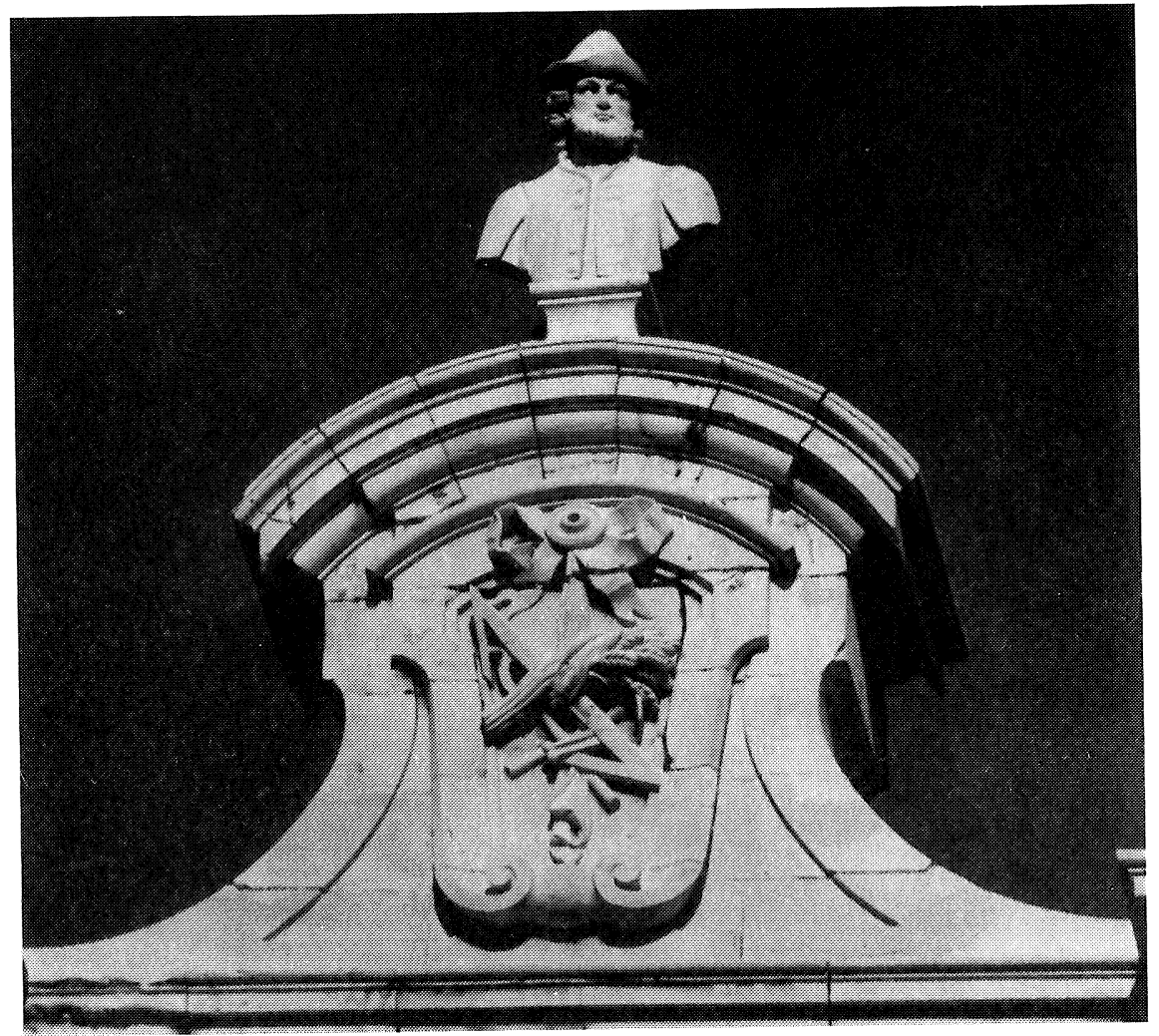


Programa iconográfico para la decoración escultórica....

Gárgoris. 1750. Fachada este

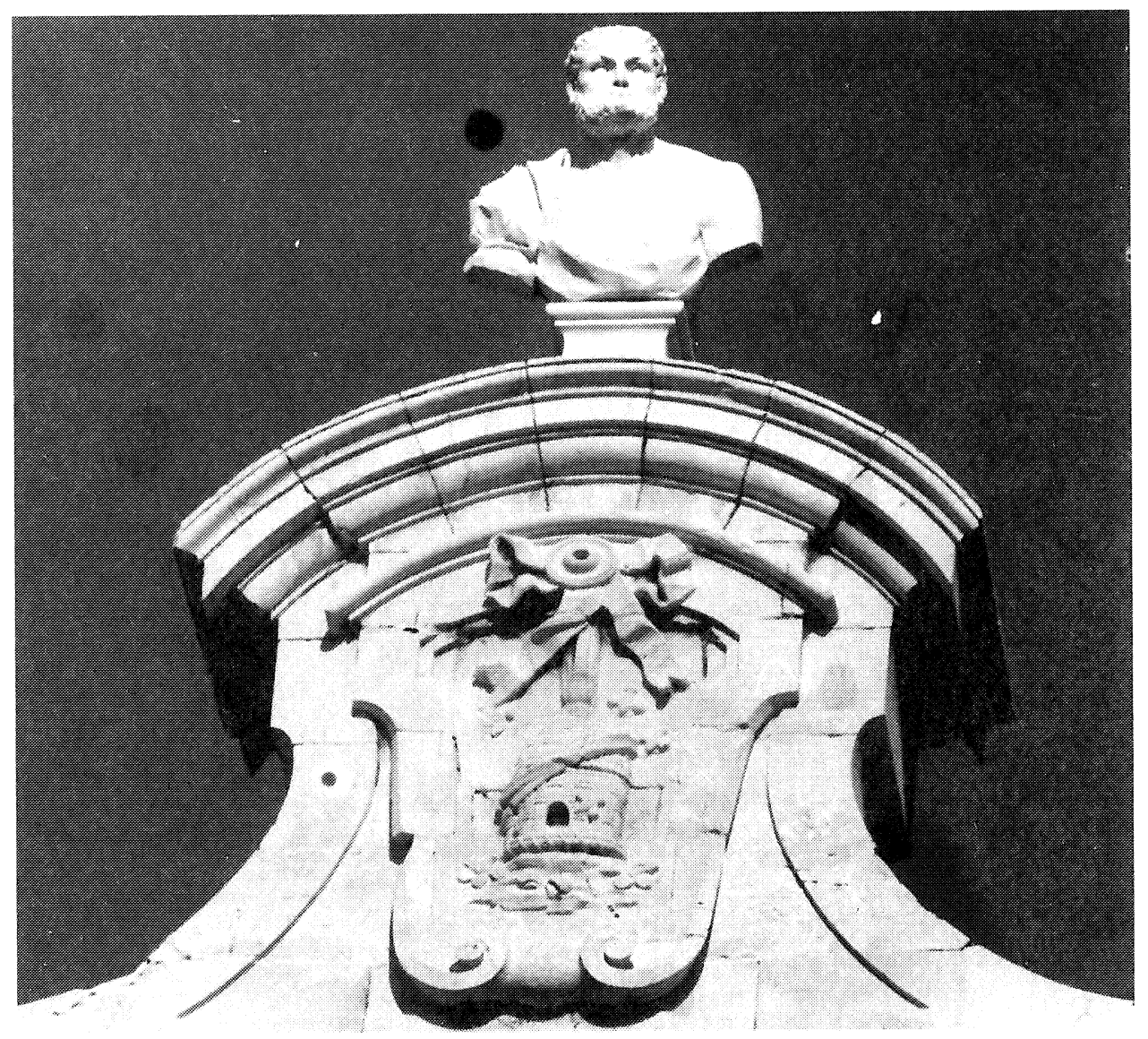


La Medalla de la España Armígera. Juan Domingo Olivieri. 1751. Fachada sur

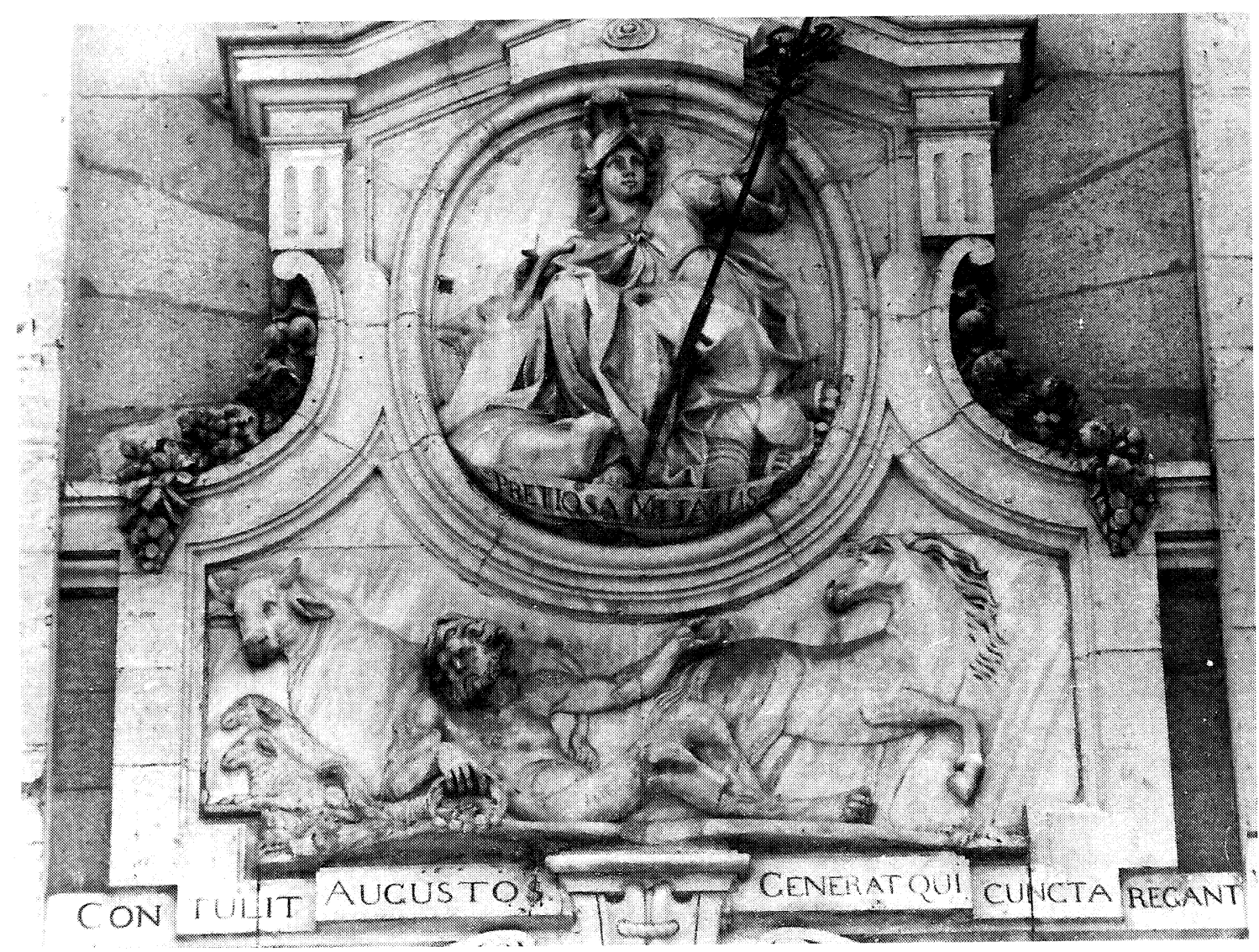




\section{Programa iconográfico para la decoración escultórica....}

Hércules. Lazaro, Jiménez y Martinengo. diseño de Olivieri. 1750. Fachada sur

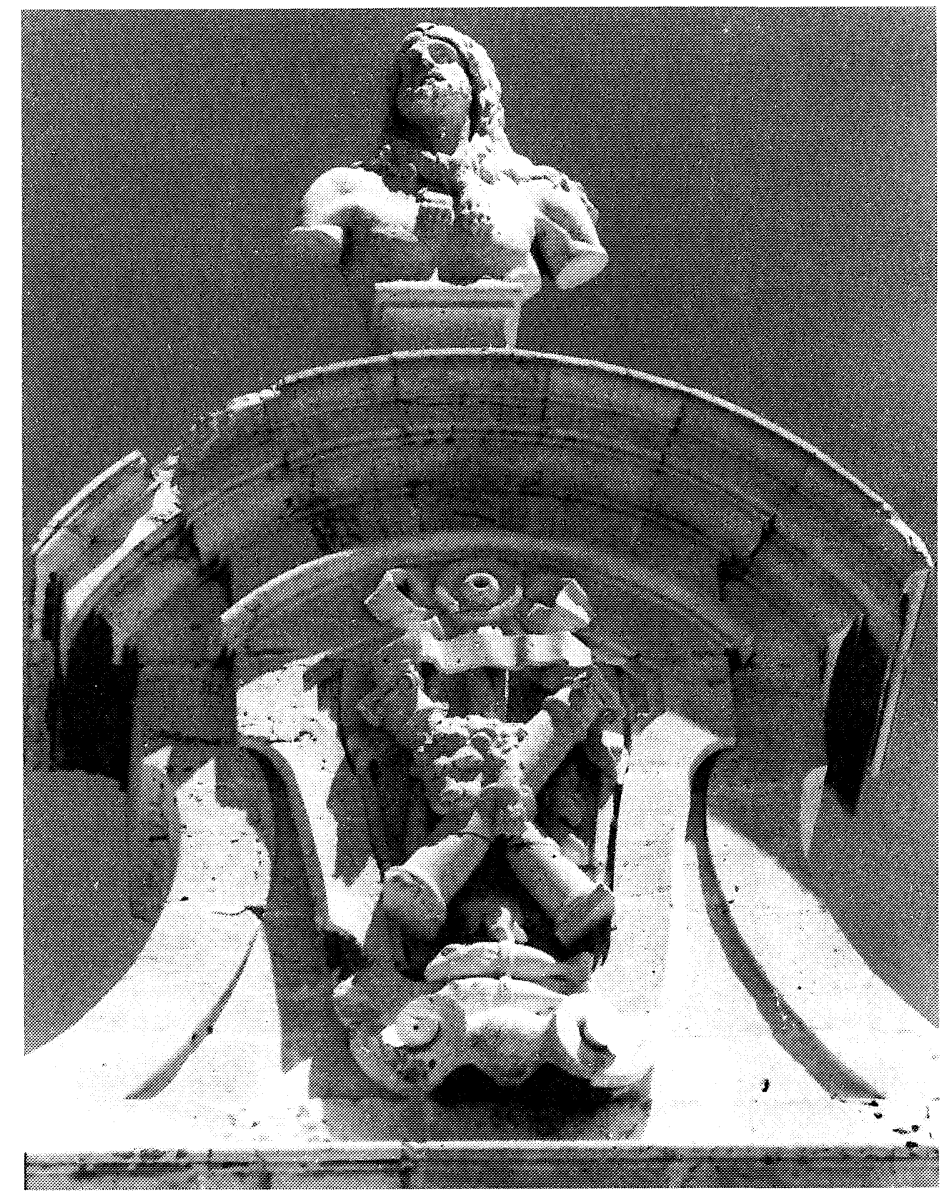


$M^{a}$ Jesús Herrero Sanz

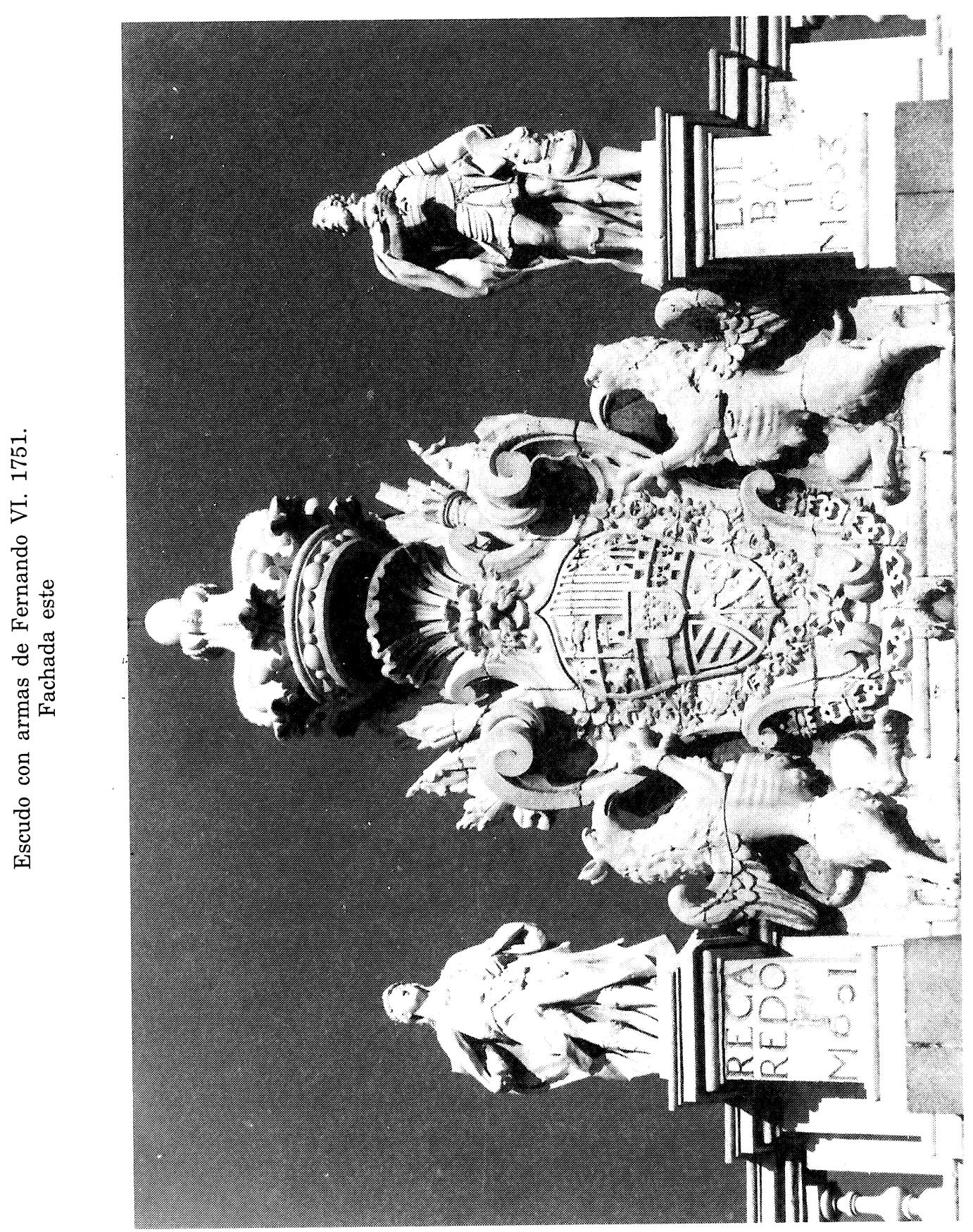






